\title{
NATURAL, ENVIRONMENTAL AND PRACTICAL BIOLOGICAL CONTROL OPTIONS FOR FUSARIUM WILT DISEASE OF CARNATION (FUSARIUM OXYSPORUM F. SP. DIANTHI)
}

\author{
ARICI, S. E. ${ }^{{ }^{*}}-$ ERDOĞAN, O. ${ }^{2}-$ TUNCEL, Z. N. ${ }^{1}$ \\ ${ }^{1}$ Isparta University of Applied Sciences, Agricultural Faculty, Department of Plant Protection, \\ 32260 Isparta, Turkey \\ ${ }^{2}$ Pamukkale University, School of Applied Sciences, Department of Organic Farming Business \\ Management, 20600 Çivril-Denizli, Turkey \\ *Corresponding author \\ e-mail: evrimarici@isparta.edu.tr \\ (Received $4^{\text {th }}$ Jul 2019; accepted $25^{\text {th }}$ Oct 2019)
}

\begin{abstract}
Carnation (Dianthus caryophyllus L.) is one of the most important cut flowers in the world. Some fungi, bacteria and viruses lead to diseases that affect carnation plants, and most of these severe diseases are caused by Fungi. It is considered that Fusarium oxysporum f. sp. dianthi (Fod) has induced one of the most serious and detrimental diseases that impair carnation. In this study, the effect of some biological preparations [Trichoderma harzianum Pseudomonas fluorescens; Bacillus subtilis QST 713 (SERENADE), Mycorrhiza spp., Trichoderma spp., Bacillus spp. (PANORAMIX), Lactobacillus acidophilus + Lactobacillus paracasei (VITANAL), tea tree oil extract (TIMOREX GOLD), orange oil extract (PREV-AM), plant extracts of Reynoutria spp. (REGALIA) against Fod were investigated. Experiments were performed using a randomized plots design with five replications (five pots and one plant per pot) in a growth chamber. After 30 days, carnation plants were evaluated with a scale of $0-5$ values. The effect of biological preparations was calculated based on root size, root number, plant height and number of nodes, then the acquired data were evaluated. The best results were obtained with $T$. harzianum (96\%), SERENADE (96\%) and PANORAMIX (88\%) against Fusarium oxysporum f. sp. dianthi. All of the control plants $(+)$ were completely dead due to the disease. In conclusion, the biological control improves the Fusarium wilt suppression capabilities of carnation.
\end{abstract}

Keywords: Pseudomonas fluorescens, Bacillus subtilis, Trichoderma harzianum, plant extract, orange oil extract

\section{Introduction}

Carnation (Dianthus caryophyllus L.) belongs to the Caryophyllaceae family and has been extremely popular amongst cut flowers since the $18^{\text {th }}$ century. Carnation is one of the most demanded cut flower in the world. Netherlands is a leading country which has the biggest market share of carnations in 2015 with around $47 \%$ of all imports in the European Union followed by The United Kingdom, Spain, Poland, Bulgaria, Slovenia, Romania and the Baltic states (https://www.cbi.eu/market-information). Turkey also has a substantial place among producers of carnation plant, which is the major horticultural product of that country. Turkey has introduced a variety of popular standards and spray for carnations to marketplace for a long time. Sixty percent of the cut flower production has comprised of carnation plant in Turkey..In addition, most of the grown cut flowers are chrysanthemums, gerberas, solidange, gladiolus and freesia. The lion's share of ornamental plant production in Turkey has been churning out between the cities of Antalya, İzmir and Yalova, and Isparta (TSI, 2016). 
Some diseases and pests lead to economic damage during the process of carnation cultivation. The most important disease is Fusarium wilt, caused by Fusarium oxysporum Schlechtend: Fr. f. sp. dianthi (Prill \& Delacr.) W. C. Snyd. \& H. N. Hans., which is a soil-borne fungus disease. Fusarium wilt disease is common in $79 \%$ of carnation production areas and affects $45 \%$ of total production (Anonymous, 2006). The most important phytopathological problem affecting carnation in most areas of the world is Fusarium wilt, caused by Fusarium oxysporum f. sp. dianthi. (Fod). Fusarium wilt is prevalent in $79 \%$ of the national production areas of carnation and affects $45 \%$ of its total production (Anonymous, 2006). The symptom of Fod is characterised by wilting of shoots, discolouration of leaves, and brown streaks on vascular tissue in stem. The infected leaves turn out chlorotic and finally wilt (Sohi, 1992). F. oxysporum f. sp. dianthi has various biological races and occurs in different carnation cultivars due to their selective virulence. Race 2 of Fod is the most prevalent in carnation cultivars (Denmik et al., 1989; Sarrocco et al., 2007). Fusarium wilting disease is controlled by systemic fungicides. This situation has a negative impact on human health, causes pollution and toxicity and also reduces the population of beneficial microorganisms in the soil. Therefore, alternative methods must be found to reduce the use of chemical fungicides. For this reason, biological control studies are of great importance. Mahalakshmi et al. (2015) investigated the effect of different organic inputs viz., neem cake, mauha cake, coipith and vermicompost against the wilt disease in carnation. As a result, Neemcake (10\%) effectively prevented the growth of Fod. Hanudin et al. (2017) reported that Bacillus subtilis and Pseudomonas fluorescens suspended in the vermicompost extract and molases on the concentration level of $0.5 \%$ were consistenly effective in suppressing Fusarium wilt on carnation. In addition, fungicides adversely affect human and environmental health. Hence, alternative control methods as biological control which are more environmentally friendly are necessary.

The aim of this study was to evaluate the effectiveness of some biological methods against Fusarium carnation wilt disease using a randomized plots design with five replications over a 30 day period, in order to find the best biological practice to combat the disease.

\section{Material and methods}

Fusarium oxysporum f. sp. dianthi (Fod) was used as a pathogen. Fod was isolated from Isparta carnation greenhouses in Turkey and tested for pathogenicity). Some biological organisms and plant extracts were utilised as a biological control. Microorganisms and plant extracts used in the experiment are given in Table 1. All treatments were applied on the carnation cuttings by root-dipping.

\section{Isolation and identification of Fusarium oxysporum $f$. sp. dianthi}

Samples exhibiting wilt disease of carnation were collected from the 5 different greenhouses of Isparta, Turkey during 2017-2018 and brought to the laboratory. From these samples five isolates of Fod were isolated and identified (Nelson et al., 1983; Burgess et al., 1994). Pathogenicity of isolates was assessed. As a result of the pathogenicity test, ISP-3 isolate, which caused the most diseases in commercial carnation cultivar was used in the experiments. 
Table 1. The biological microorganisms and plant extracts used in the experiment

\begin{tabular}{c|c}
\hline Treatments & Number of plant \\
\hline Trichoderma harzianum & 5 \\
Pseudomonas fluorescens & 5 \\
Bacillus subtilis QST 713 (SERENADE) & 5 \\
Mycorrhiza spp., Trichoderma spp., Bacillus spp (PANORAMIX) & 5 \\
Lactobacillus acidophilus + Lactobacillus paracasei (VITANAL) & 5 \\
Tea tree oil extract (TIMOREX GOLD) & 5 \\
Orange oil extract (PREV-AM) & 5 \\
Plant extracts of Reynoutria spp. (REGALIA) & 5 \\
\hline
\end{tabular}

\section{Isolation of Trichoderma harzianum, Pseudomonas fluorescens}

Trichoderma harzianum and Pseudomonas fluorescens were isolated by dilution plate technique from the soil samples collected from Isparta and Aydin, in Turkey (Johanson, 1957). The fungal isolate was grown on PDA plates, the bacteria isolate was grown on Nutrient Agar (HIMEDIA, $13 \mathrm{~g} / \mathrm{L}$ ) media at $25^{\circ} \mathrm{C}$. The isolated species were identified by Rhodes (1959), Whipps (2001) and Chin et al. (2003). The isolates of $T$. harzianum and Pseudomonas fluorescens were kept on the PDA/NA medium in the Biotechnology and Plant Pathology Research Laboratory, Isparta University of Applied Sciences, Isparta.

\section{Plant material}

The commercial carnation cultivar of Picasso was used for its potential antagonistic capacity to Fusarium carnation wilt disease reaction in a growth chamber condition.

\section{Treatment and assessment}

Pseudomonas fluorescens were grown in Nutrient Agar (HIMEDIA, $13 \mathrm{~g} / \mathrm{L}$ ) medium and placed at $90 \mathrm{rpm}$ on a rotary shaker for $48 \mathrm{~h}$ at room temperature. The cells were harvested by centrifugation for $15 \mathrm{~min}$ at $5000 \mathrm{rpm}$ and the pellet was suspended in distilled water. Suspension of bacteria was adjusted to $1 \times 10^{7} \mathrm{cfu} / \mathrm{ml}$. The isolates of $T$. harzianum and $F$. oxysporum $\mathrm{f}$. sp. dianthii were cultured in PDA plates and incubated at $25{ }^{\circ} \mathrm{C}$ for 10 days. Sterile distilled water was poured on the mycelium of fungi and mycelia were collected with a scalpel and the liquid was taken out. Suspensions were then filtered through sterilized cotton filters to obtain pure conidial suspensions and the spores were counted by using a hemocytometer. The spore suspensions of both fungi were adjusted to $1 \times 10^{6}$ conida/mL concentration with sterile distilled water. When plants had 6-8 true-leaf stages, all treatments (REGULAR-200 ml/100 L, TIMOREX200 ml/100 L, PREW-AM 200 ml/100 L, VITANOL-300 ml/100 L, PANORAMIX$600 \mathrm{ml} / 100 \mathrm{~L}$, SERENADE-1000 ml/100 L, T. harzianum- $1 \times 10^{6}$ conida/mL), $P$. fluorescens $-1 \times 10^{7} \mathrm{cfu} / \mathrm{ml}$.) were applied on the carnation cuttings by root-dipping for $30 \mathrm{~min}$ using $20 \mathrm{~mL}$ per plant. Treated plants were separately planted in pots with 2 torf: 1 perlit: substrate and the remainder suspensions were added to the pots. After $48 \mathrm{~h}$, inoculum suspension of $F$. oxysporum $\mathrm{f}$. sp. dianthii were added using $20 \mathrm{ml}$ per plant. The plants were transferred to growth chambers at $24{ }^{\circ} \mathrm{C}$ and 12 -h day/12-h night for 30 days (Fig. 1). Experiments were performed using a randomized plots design with five 
replications (five pots and one plant per pot) in a growth chamber. The experiment was repeated twice. Diseases severity was evaluated 30 days after inoculation with a 0-5 scale values as follows: $0=$ no symptoms $(0 \%$ disease); $1=$ weakly affected plant $(5 \%)$; $2=$ local base-stem symptoms (20\%); $3=$ one-sided and well-developed symptoms $(50 \%) ; 4=$ severe disease symptoms throughout the plant $(80 \%) ; 5=$ dead plant $(100 \%)$ (Baayen and van der Plas, 1992).

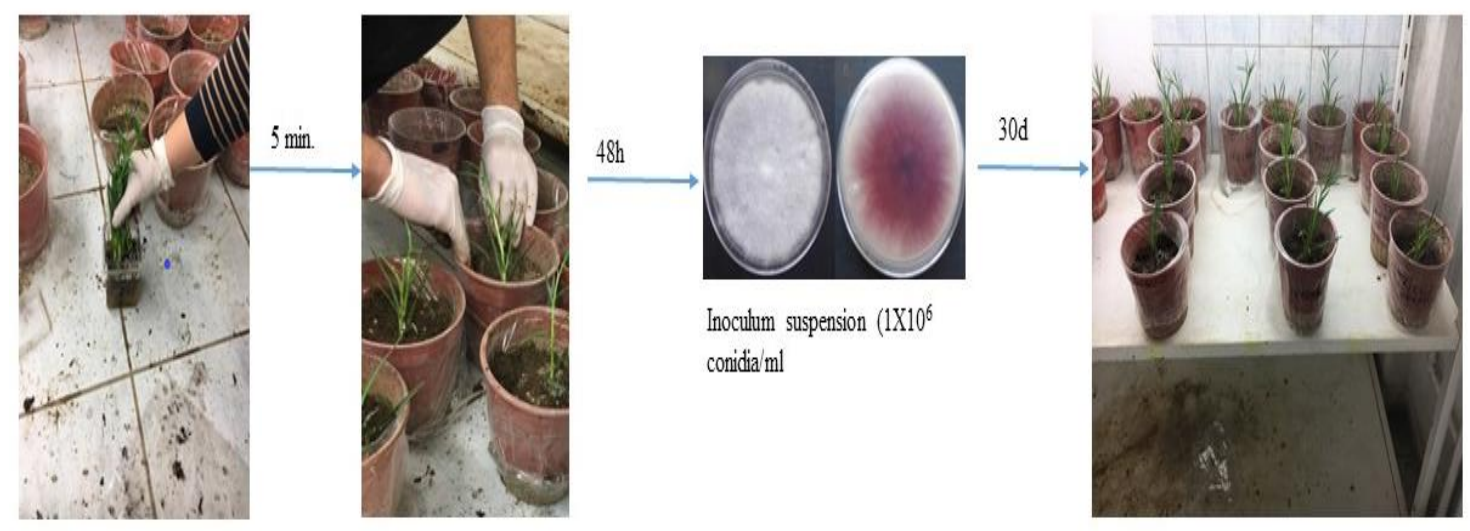

Figure 1. Different treatment against Fod on carnation cv Picasso in a growth chamber

The disease severity was monitored every week throughout experimental procedure. The disease severity was evaluated using Townsend-Heuberger's formula (Towsend and Heuberger, 1943). The percentage effect of the applications was calculated using the Abbott formula (Abbott, 1925). The effect of biological preparations (\%) was calculated, root size $(\mathrm{cm})$, root number, plant height $(\mathrm{cm})$, number of nodes were measured. Control plant groups were used in the experiment, and control positive plants groups were applied only to Fod and control negative plants only water was applied.

All data were analyzed by analysis of variance (ANOVA) to detect differences between treatments. Mean comparisons were made by using Duncan's tests; all statistical tests were conducted at a probability level of $\mathrm{P} \leq 0.05$. All analyses were performed using the SPSS 21 software.

\section{Results}

Trichoderma harzianum, P. fluorescens, B. subtilis QST 713 (SERENADE), Bacillus spp + Trichoderma spp. + Endomycorrhiza (PANORAMIX), L. acidophilus + L. paracasei (VITANAL), and plant extracts of Tea tree oil extract (TIMOREX GOLD), Orange oil extract (PREV-AM), Reynoutria spp. (REGALIA) were applied to carnation wilt disease caused by $F$. oxysporum f. sp. dianthi. All applications reduce disease symptoms significantly (Fig. 2).

The lowest disease severity (\%) was obtained from $P$. fluorescens (4\%), SERENADE (6\%), and T. harzianum (10\%) to Fod. Disease severity (\%) was determined in the application of PANORAMIX (12\%). The percentage of disease severity in control plants was observed as $96 \%$ (Fig. 3). In the experiment, it was determined that the highest percentage of efficacy values of the biological preparations were for P. fluorescens (96\%), SERENADE (94\%), and T. harzianum (90\%) to Fod. 
Control plant groups (+) were completely dead due to the disease. The lowest percentage of efficacy values of the biological preparations were determined with the application of TIMOREX (76\%), VITANAL and REGALIA (72\%). In conclusion, the biological control method improves the suppressive capacity against Fusarium wilt disease in carnation (Table 2).

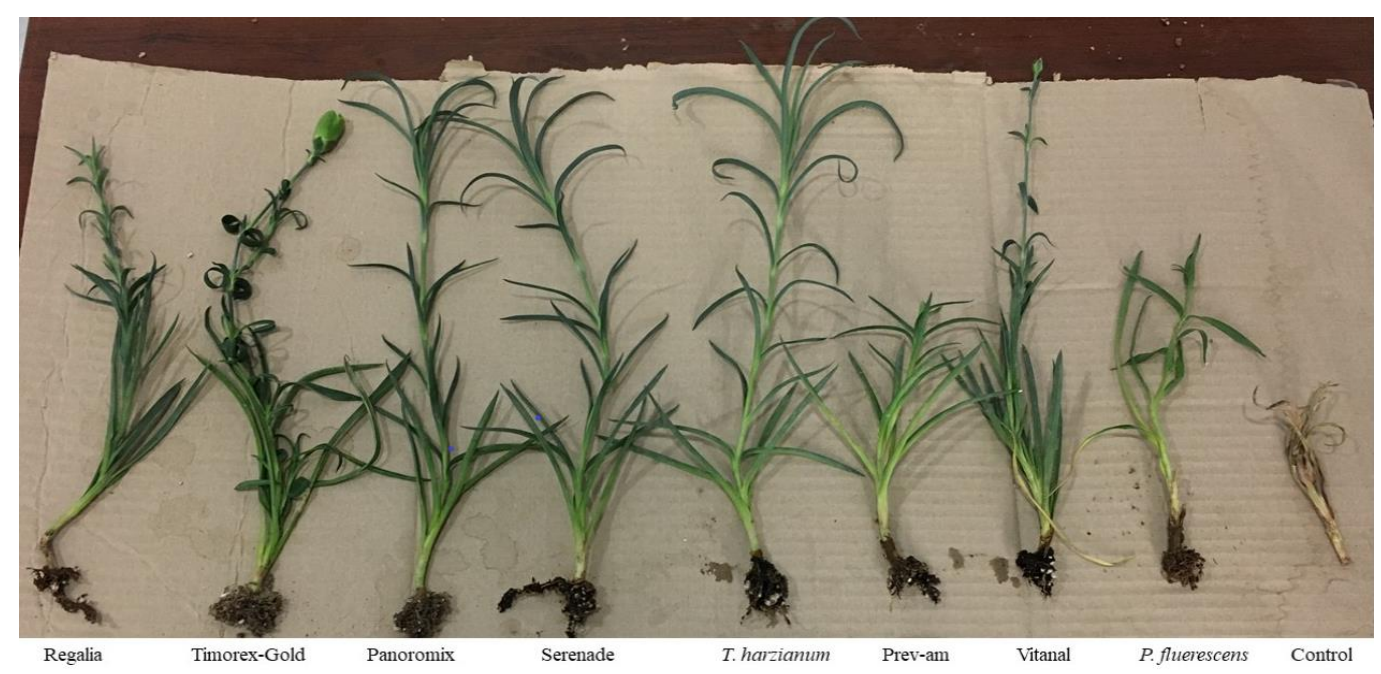

Figure 2. Effects of different treatments on Fod incidence on pot assay in a growth chamber

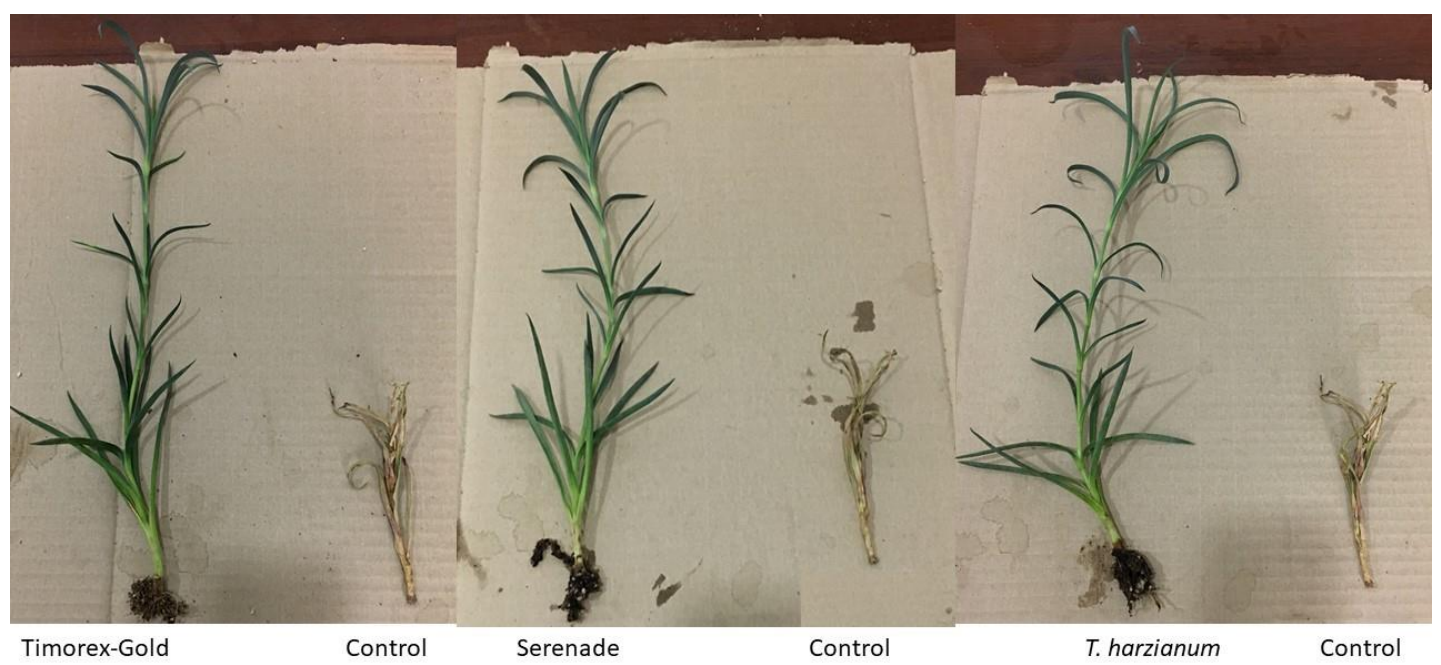

Figure 3. Effects of SERENADE, TIMOREX GOLD and T. harzianum on plant growth

The effect of different treatments on plant parameters of carnation was presented in Table 3. Statistical analysis of figure showed significant differences in treatments at $\mathrm{P} \leq 0.05$ levels. Application of different treatments have improved carnation growth statistically. Plant height was showed significant variation with TIMOREX GOLD application. The longest plant height was found in TIMOREX GOLD application $(31.60 \mathrm{~cm})$ followed by PANORAMIX $(26.46 \mathrm{~cm})$, REGALIA $(26.44 \mathrm{~cm})$ and SERENADE $(25.98 \mathrm{~cm})$ ) applications. The shortest plant height were in P. Fluorescens 
$(21.25 \mathrm{~cm})$ application. Significant variation was observed in the case of the number of roots with different treatments. The maximum root number was in TIMOREX GOLD application with 23.20, the minimum number of root was determined in PREV-AM with 11.60. The root length was showed significant variation with different treatments. The maximum root length was determined on REGALIA application $(4.28 \mathrm{~cm})$. Significant variation was determined in the case of the number of nodes. It was indicated that the maximum number of node (9.00) was found VITANAL and REGALIA, the minimum number of node (5.60) was in P. fluorescens. Results showed that TIMOREX GOLD, REGALIA and SERENADE in generally were found effective to enhance the plant growth percentage compared to control.

Table 2. Effectiveness of different treatments against $F$. oxysporum $f$. sp. dianthi on carnation

\begin{tabular}{c|c|c}
\hline Treatments & DS* & E* \\
\hline Orange oil extract (PREV-AM) & 20.0 & $80.0 \mathrm{ab}$ \\
T. harzianum & 10.0 & $\mathbf{9 0 . 0} \mathbf{a}$ \\
B. subtilis QST 713 (SERENADE) & 6.0 & $\mathbf{9 4 . 0} \mathbf{~ a}$ \\
L. acidophilus + L. paracasei (VITANAL) & 28.0 & $72.0 \mathrm{bc}$ \\
P. fluorescens & 4.0 & $\mathbf{9 6 . 0} \mathbf{a}$ \\
Mycorrhiza spp., Trichoderma spp., Bacillus spp (PANORAMIX) & 12.0 & $88.0 \mathrm{ab}$ \\
Tea tree oil extract (TIMOREX GOLD) & 24.0 & $76.0 \mathrm{~b}$ \\
Plant extracts of Reynoutria spp. (REGALIA) & 28.0 & $72.0 \mathrm{bc}$ \\
Control (+) & 96.0 & \\
\hline
\end{tabular}

*Mean values with the same letter within a column are not significantly different at the $\mathrm{P} \leq 0.05$ probability level by Duncan, DS: Disease severity (\%), E: Effect (\%)

Table 3. Effectiveness of different treatments on root length (cm), number of root, plant height $(\mathrm{cm})$ and node number on carnation

\begin{tabular}{|c|c|c|c|c|}
\hline Treatments & RL* & NR* & PH* & NN* \\
\hline Orange oil extract (PREV-AM) & $2.40 \mathrm{bc}$ & $11.60 \mathrm{e}$ & $22.30 \mathrm{~b}$ & $7.20 \mathrm{ab}$ \\
\hline T. harzianum & $2.40 \mathrm{bc}$ & $17.20 \mathrm{bcd}$ & $22.56 \mathrm{~b}$ & $8.40 \mathrm{a}$ \\
\hline B. subtilis QST 713 (SERENADE) & $2.82 \mathrm{~b}$ & $14.60 \mathrm{bcd}$ & 25.38 ab & $8.20 \mathrm{ab}$ \\
\hline L. acidophilus + L. paracasei (VITANAL) & $2.14 \mathrm{bc}$ & $18.00 \mathrm{abc}$ & $21.30 \mathrm{~b}$ & $9.00 \mathrm{a}$ \\
\hline P. fluorescens & $1.66 \mathrm{c}$ & $14.00 \mathrm{bcd}$ & $21.25 \mathrm{~b}$ & $5.60 \mathrm{~b}$ \\
\hline Mycorrhiza spp., Trichoderma spp., Bacillus spp (PANORAMIX) & $2.54 \mathrm{bc}$ & $14.20 \mathrm{bcd}$ & $24.46 \mathrm{ab}$ & $8.20 \mathrm{ab}$ \\
\hline Tea tree oil extract (TIMOREX GOLD) & $2.82 \mathrm{~b}$ & 23.20 a & $31.60 \mathrm{a}$ & $8.20 \mathrm{ab}$ \\
\hline Plant extracts of Reynoutria spp. (REGALIA) & $4.28 \mathrm{a}$ & $15.66 \mathrm{bcd}$ & $26.44 a b$ & $9.00 \mathrm{a}$ \\
\hline Control (-) & $1.59 \mathrm{c}$ & $19.60 \mathrm{ab}$ & $22.00 \mathrm{~b}$ & $8.00 \mathrm{ab}$ \\
\hline
\end{tabular}

**Mean values with the same letter within a column are not significantly different at the $\mathrm{P} \leq 0.05$ probability level by Duncan, RL: Root length (cm), NR: Number of root, PH: Plant height (cm), NN: Node number

\section{Discussion}

In this study, $F$. oxysporum $\mathrm{f}$. sp. dianthi was significantly reduced by several microorganisms and plant extracts. In the experiment, it was determined that the highest percentage of efficacy values of the biological preparations were for $P$. fluorescens, SERENADE and T. harzianum to Fod. In addition, the application of SERENADE, TIMOREX GOLD and REGALIA increased plant height. SERENADE, T. harzianum and $P$. fluorescens are very common biocontrol agents against the pathogen. Biocontrol 
bacteria and fungi produce multiple antibiotics that eliminate plant pathogen bacteria and fungi (Strange, 2007; Wang et al., 2016). Trichoderma spp. produce various antibiotics, such as viridin, gliotoxin, polyketides and pyrones, against fungal phytopathogens (Howell, 2003; Harman et al., 2004; Naher et al., 2014). Bacillus spp. include bacitracin, mycosubtilin polymyxin, bacillomycins and gramicidin and they inhibit fungal germination, suppress of some plant pathogen. One of the most important antibiotics compound produced by $P$. fluorescens is pyrollnitrin, which inhibited growth of some plant fungal pathogens (Karimi et al., 2012; Santoya et al., 2012; Chapelle et al., 2016).

Competition for nutrients and plant surface is another mechanism for plant pathogens. Competitive exception of pathogens as the result of fast colonization of the rhizosphere or plant surface by biological fungus and bacteria may also be an important factor in the control of plant pathogens. Biocontrol species have a higher affinity for nutrients especially iron, phosphorus, nitrogen and can stimulate plant growth directly by or indirectly. They can suppress a broad spectrum of bacterial, fungal and nematode diseases (Jan et al., 2011).

Many biocontrol bacteria and fungi induced systemic resistance which is characterised by a broad spectrum of resistance against pathogens (Conrath et al., 2006; Pieterse et al., 2014; O'Brien, 2017). Beneficial microbes elicite the signalling pathways, and stimulate the host's immune system. Biocontrol bacteria and fungus induced systemic resistance (ISR), may also contribute to disease suppressiveness (Beredsen et al., 2018).

Plant extracts and essential oils appeared to be efficient to control $F$. oxysporum $\mathrm{f}$. sp. dianthi. Some research studies reported the efficacy of REGALIA in controlling bacterial spot of tomatoes and peppers (Botrytis spp. of grapes and strawberries, powdery mildew of cucurbits, downy mildew of lettuce (Bremia lactucae), Cercospora on soybeans (Cercospora kikuchii), Cercospora zeae-maydis; Podospheria leucotricha, Venturia inaequalis, bacterial canker on citrus (Xanthomonas axonopodis pv. citri), Xanthomonas campestris pv. vesicatoria and Xanthomonas euvesicatoria ( $\mathrm{Su}, 2012$; Worthington et al., 2012; Harbou and Jaksen Ziems, 2015; Delong et al., 2018). Many beneficial bacteria and fungi have a general plant growth promoting effect, and produce analogues of plant growth regulatory hormones, volatile compounds to stimulate plant growth. (Harman et al., 2004; Taghavi et al., 2009; Hermosa et al., 2012; Rashid et al., 2012; Truyens et al., 2014). Some beneficial microorganism is able to establish a symbiotic relationship with plants and they increase the availability of these nutrients to plants (Gutiérrez-Luna et al., 2010; Saharan and Nehra, 2011). Its beneficial effects of Trichoderma sp. on beside abiotic stress have been well documented (Donoso et al., 2008; Mastouri et al., 2010, Roatti et al., 2013).

In our experiment, the application of TIMOREX GOLD significantly reduced the Fod. TIMOREX GOLD components include cineole cymene, linalool and terpinen-4-ol (Carson et al., 2006; Goni et al., 2014; Wei et al., 2018). The plant oil and plant extracts include secondary chemical compounds such as terpenes, alcohols, aldehydes and phenols, and these materials exhibit fungicidal potential (Zanellato et al., 2009). Essential oil from tea tree oil extract has shown promising results in reducing disease occurrence and severity induced by Cercospore beticola in sugar beets, and Alternari solani in potato (Caolotanski et al., 2002). It was also reported that tea tree oil was effective against Fusarium head blight in wheat, barley and oats, barley leaf stripe and powdery mildew Terzi et al., 2007). The application of tea tree oil at $2.0 \%$ inhibited the 
mycelium growth of Botrytis oryzae, Alternaria brassicicola, Fusarium moniliforme, Aspergillus flavus, Fusarium proliferatum (Thobunluepop et al., 2009).

\section{Conclusion}

It has been observed that the treatments had a positive effect against the $F$. oxysporum f. sp. dianthi and the plant growth of carnation. Biological control method seems to be safe and environmentally friendly and an alternative method with respect to fungicides. Utilization of beneficial microorganisms could be a common agricultural practice in the near future. In addition, biological control methods might be combined with other control methods, but additional research is needed to develop methods of incorporation of biological organisms into other control strategies for the carnation wilt disease management. It is helpful to conduct an extended study that identifies the microorganisms and plant extracts used in the experiment under greenhouse conditions against Fod and carnation plant growth.

Acknowledgements. We would like to thank Assoc. Prof. Dr. Özgür KOŞKAN for his helps in statistical analysis.

Conflict of interests. The authors declare that they have no conflict of interests.

Funding. This study was not supported by any Research Fund.

Ethical approval. For this type of study formal consent is not required.

Informed consent. Informed consent was obtained from all individual participants included in the study.

Author contributions. The research was conducted by S. Evrim ARICI and Oktay ERDOĞAN. The experiment was carried out by Evrim ARICI, Oktay ERDOĞAN and Zinnet Nurcin TUNCEL. The article was written by Evrim ARICI.

\section{REFERENCES}

[1] Abbott, W. S. (1925): A method of computing the effectiveness of an insecticide. - J Econ Entom 18: 265-267.

[2] Anonymous (2006): Anuario De Estadística Agroalimentaria (Cap.). - Ministerio de Agricultura Pescay Alimentación, Spain 12: 1-13.

[3] Baayen, R. P., Van der Plas, C. H. (1992): Localization ability, latent period and wilting rate in eleven carnation cultiva rs with partial resistance to Fusarium Wilt. - Euphytica 59: 165-174.

[4] Berendsen. R. L., Vismans, G., Yu, K., Song, Y., de Jonge, R., Burgman, W. P., Burmølle, M., Herschend, J., Bakker, P. A. H. M., Pieterse, C. M. J. (2018): Diseaseinduced assemblage of a plant-beneficial bacterial consortium. - ISME J. https://doi.org/10.1038/s41396-018-0093-1.

[5] Burgess, L. W., Summerell, B. A., Bullock, S., Got, K. P., Backhouse, D. (1994): Laboratory Manual for Fusarium Research. $3^{\text {rd }}$ Ed. - Univ. of Sydney, Sydney.

[6] Caolotanski, J. M., Hanson, L. E., Hill, A. L., Hill, J. P. (2002): Use of Melaleuca alternifolia oil for plant disease control. - Phytopathology 92(6): S12.

[7] Carson, C. F., Hammer, A., Riley, T. V. (2006): Melaleuca alternifolia (tea tree) oil: a review of antimicrobial and other medicinal properties. - Clinical Microbiology Reviews 2006(1): 50-62.

[8] Chapelle, E., Mendes, R., Bakker, P. (2016): Fungal invasion of the rhizosphere microbiome. - ISME J 10: 265-268. 
[9] Chin-A-Woeng, T. F., Bloemberg, G. V., Lugtenberg, B. J. (2003): Phenazines and their role in biocontrol by Pseudomonas Bacteria. - New Phytology 157: 503-523.

[10] Conrath, U., Beckers, G. J. M., Flors, V., Garcia-Agustin, P., Jakab, G., Mauch, F., Newman, M. A., Pieterse, C. M. J., Poinssot, B., Pozo, M. J., Pugin, A., Schaffrath U., Ton J., Wendehenne D., Zimmerli L., Mauch-Mani B. (2006): Prime APG priming: getting ready for battle. - Molecular Plant-Microbe Interactions 19: 1062-1071.

[11] DeLong, C. N., Yoder, K. S., Cochran, A. E., Kilmer, S. W., Royston, W. S., Combs, 1. D. (2018): Apple disease control and bloom-thinning effects by lime sulfur, regalia, and JMS stylet-oil. - Plant Health Programme Jan 19(2): 143-52.

[12] Denmik, J. F., Baayen, R. P. and Sparnaaij, L. D. (1989): Evaluation of the virulence of race 1, 2 and 4 of Fusarium oxysporum, f. sp. dianthi in carnation. - Euphytica 42: 55-63.

[13] Donoso, E. P., Bustamante, R. O., Caru, M., Niemeyer, H. M. (2008): Water deficit as a driver of the mutualistic relationship between the fungus Trichoderma harzianum and two wheat genotypes. - Applied and Environmental Microbiology 74: 1412-1417.

[14] Goñi, M. G., Tomadoni, B., Roura, S. I., Moreira, M. R. (2014): Effect of preharvest application of chitosan and tea tree essential oil on postharvest evolution of lettuce native microflora and exogenous Escherichia coli O157:H7. - Journal of Food Safety 34: 353360.

[15] Gutiérrez-Luna, F., López-Bucio, J., Altamirano-Hernández, J., Valencia-Cantero, E., Cruz, H., Macías-Rodríguez, L. (2010): Plant growth-promoting rhizobacteria modulate root-system architecture in Arabidopsis Thaliana through volatile organic compound emission. - Symbiosis 51: 75-83.

[16] Hanudin Nuryani, W., Silvia Yusuf, E., Djatnika, I., Soedarjo, M. (2011): Comparison of inoculation techniques and selection of antagonist bacteria to control white rust disease on chrysanthemum. - The Journal of Horticultural Science 21(2): 173-184.

[17] Harbour, J. D., Jackson-Ziems, T. A. (2015): The effects of fungicides and regalia tank mixtures on fray leaf spot in Nebraska Field Corn. - Papers in Plant Pathology 499. http://digitalcommons.unl.edu/plantpathpapers/499.

[18] Harman, G. E., Howell, C. H., Viterbo, A., Chet, I., Lorito, M. (2004): Trichoderma species - opportunistic, avirulent plant symbionts. - Nature Reviews Microbiology 2: 4356.

[19] Hermosa, R., Viterbo, R., Chet, I., Monte, R. (2012): Plant-beneficial effects of trichoderma and of its genes. - Microbiology 158: 17-25.

[20] Howell, C. R. (2003): Mechanisms employed by Trichoderma species in the biological control of plant diseases: the history and evolution of current concepts. - Plant Disease 87: 4-10.

[21] Jan, A. T., Azam, M., Ali, A., Haq, Q. M. R. (2011): Novel approaches of beneficial pseudomonas in mitigation of plant diseases-an appraisal. - Journal of Plant Interactions 6: 195-205. DOI: 10.1080/17429145.2010.541944.

[22] Johnson, L. A. (1957): Effect of antibodies on the number of bacteria and fungi isolated from soil by dilution plate method. - Phytopathology 47: 21-22.

[23] Karimi, K., Amini, J., Harighi, B., Bahramnejad, B. (2012): Evaluation of biocontrol potential of Pseudomonas and Bacillus spp. against Fusarium Wilt of chickpea. Australian Journal of Crop Science 6: 695-703.

[24] Mahalakshmi, P., Mohan, S., Theradimani, M. (2015): Evaluation of tree borne oil cakes for the management of Fusarium wilt of carnation (Dianthus caryophllus L.) caused by Fusarium oxysporum f. sp. Dianthi P. - Advances in Tree Seed Science and Silviculture, 164-171.

[25] Mastouri, F., Bjorkman, T., Harman, G. E. (2010): Seed Treatment with Trichoderma harzianum alleviates biotic, abiotic, and physiological stresses in germinating seeds and seedlings. - Phytopathology 100: 1213-1221. 
[26] Naher, L., Yusuf, U., Ismail, A., Hossain, K. (2014): Trichoderma spp.: a biocontrol agent for sustainable management of plant diseases. - Pakistan Journal of Botany 46(4): 1489-1493.

[27] Nelson, P. E., Toussoun, T. A., Marasas, W. F. O. (1983): Fusarium Species. An Illustrated Manual for Identification. - The Penn State University Press, University Park, Pennsylvania.

[28] O'Brien, P. A. (2017): Biological control of plant diseases. - Australasian Plant Pathology 44: 1-12. DOI: 10.1007/s13313-017-0466-3.

[29] Pieterse, C. M. J., Zamioudis, C., Berendsen, R. L., Weller, D. M., Van Wees, S. C. M., Bakker, P. (2014): Induced systemic resistance by beneficial microbes. - Annual Review of Phytopathology 52: 347-375. DOI: 10.1146/annurevphyto-082712-102340.

[30] Rashid, S., Charles, T. C., Glick, B. R. (2012): Isolation and characterization of new plant growth-promoting bacterial endophytes. - Applied Soil Ecology 61: 217-224.

[31] Rhodes, M. E. (1959): The characterization of Pseudomonas Jluorescens. - Journal of General Microbiology 21: 221.

[32] Roatti, B., Perazzolli, M., Gessler, C., Pertot, I. (2013): Abiotic stresses affect Trichoderma harzianum t39-induced resistance to downy mildew in grapevine. Phytopathology 103(12): 1227-1234.

[33] Saharan, B., Nehra, V. (2011): Plant growth promoting rhizobacteria: a critical review. Life Sciences Med Research 21: 1-30.

[34] Santoyo, G., Orozoco-Mosqueda, M. C., Govindappa, M. (2012): Mechanisms of biocontrol and plant growth-promoting activity on soil bacterial species of bacillus and pseudomonas: a review. - Biocontrol Science and Technology 22: 855-872.

[35] Sarrocco, S., Falaschi, N., Vergara, M., Nicoletti, F., Vannacci, G. (2007): Use of Fusarium oxysporum $\mathrm{f}$. sp. dianthi transformed with marker genes to follow colonization of carnation roots. - Journal of Plant Pathology 89: 61-68.

[36] Sohi, H. S. (1992): Diseases of Ornamental Plants in India. - Publication and Information Division, Indian Council of Agricultural Research, Krishi Anusandhan Bhavan, New Delhi.

[37] Strange, R. N. (2007): Phytotoxins produced by microbial plant pathogens. - Natural Product Reports 24: 127-144. DOI: 10.1039/b513232k.

[38] Su, H. (2012): REGALIA® bioprotectant in plant disease management. - Outlooks on Pest Management 23(1): 30-34.

[39] Taghavi, S., Garafola, C., Monchy, S., Newman, L., Hoffman, A., Weyens, N., Barac, T., Vangronsveld, J., Vander Lelie, D. (2009): Genome survey and characterization of endophytic bacteria exhibiting a beneficial effect on growth and development of poplar trees. - Applied and Environmental Microbiology 75: 748-757.

[40] Terzi, V., Morcia, M., Faccioli, P., Valè, G., Tacconi, G., Malnati, M. (2007): In vitro antifungal activity of the tea tree (Melaleuca alternifolia) essential oil and its major components against plant pathogens. - Letters in Applied Microbiology 44(6): 613-618.

[41] Thobunluepop, P., Udomsilp, J., Piyo, A., Khaengkhan, P. (2009): Screening for the antifungal activity of essential oils from bergamot oil (Citrus hystrix DC.) and tea tree oil (Melaleuca alternifolia) against economically rice pathogenic fungi: a driving force of organic rice Cv. KDML 105 production. - Asian Journal of Food \& Agro-Industry Special Issue: S374-S380.

[42] Townsend, G. K., Heuberger, W. (1943): Methods for estimating losses caused by diseases in fungicide experiments. - Plant Disease Report 27: 340-343.

[43] Truyens, S., Weyens, N., Cuypers, A., Vangronsveld, J. (2014): Bacterial seed endophytes: genera, vertical transmission and interaction with plants. - Environmental Microbiology Reports 7: 40-50.

[44] TSI (2016): Türkiye İstatistik Kurumu (TÜIK). http://www.tuik.gov.tr/PreTablo.do?alt_id=1001 Erişim tarihi: 23.08.2017A. 
[45] Wang, M. C., Tachibana, S., Murai, Y., Li, L., Lau, S. Y. L., Cao, M. C., Zhu, G. N., Hashimoto, M., Hashidoko, Y. (2016): Indole-3-acetic acid produced by Burkholderia heleia acts as a phenylacetic acid antagonist to disrupt tropolone biosynthesis in Burkholderia plantarii. - Scientific Reports 6: 22596-22596.

[46] Wei, Y., Shao, X., Wei, Y., Xu, F., Wang, H. (2018): Effect of preharvest application of tea tree oil on strawberry fruit quality parameters and possible disease resistance mechanisms. - Scientia Horticulturae 241: 18-28.

[47] Whipps, J. M. (2001): Microbial interactions and biocontrol in the rhizosphere. - Journal of Experimental Botany 52: 487-511.

[48] Worthington, R. J., Rogers, S. A., Huigens, R. W., Melander, C., Ritchie, D. F. (2012): Foliar-applied small molecule that suppresses biofilm formation and enhances control of copper-resistant Xanthomonas euvesicatoria on pepper. - Plant Disease 96(11): 1638-44. DOI: 10.1094/PDIS-02-12-0190-RE.

[49] Zanellato, M., Masciarelli, E., Casorri, L., Boccia, P., Sturchio, E., Pezzella, M., Cavalieri, A., Caporali, F. (2009): The essential oils in agriculture as an alternative strategy to herbicides: a case study. - International Journal of Environment and Health 3(2): 198-213. 